\title{
Countering resistance to protected-area extension
}

David Lindenmayer, Fenner School of Environment and Society, The Australian National University, Canberra, ACT 2601, Australia, email david.lindenmayer@anu.edu.au

Simon Thorn, Field Station Fabrikschleichach, Biocenter University of Würzburg, Glashüttenstraße 5, 96181 Rauhenebrach; Bavarian Forest National Park, Freyunger Str. 2, 94481 Grafenau, Germany

Reed Noss, Florida Institute for Conservation Science, 2205 Sultan Circle, Chuluota, FL 32766, USA, and Nicholas School of the Environment, Duke University, Durham, NC 27708, U.S.A.

\section{Article Impact Statement}

The establishment of protected areas is crucial to conserve biodiversity but cannot be achieved without support from local communities.

Running head: Protected-Area Extension

Keywords: conservation policy, conservation targets, zoning, biodiversity, stakeholders 


\begin{abstract}
The establishment of protected areas is a critical strategy for conserving biodiversity. Key policy directives like the Aichi targets seek to expand protected areas to $17 \%$ of Earth's land surface, with calls by some conservation biologists for much more. However, in places such as the United States, Germany, and Australia, attempts to increase protected areas are meeting strong resistance from communities, industry groups, and governments. We examined case studies of such resistance in Victoria, Australia, Bavaria, Germany, and Florida, United States. We considered 4 ways to tackle this problem. First, broaden the case for protected areas beyond nature conservation to include economic, human health, and other benefits, and translate these into a persuasive business case for protected areas. Second, better communicate the conservation values of protected areas. This should include highlighting how many species, communities, and ecosystems have been conserved by protected areas and the counterfactual (i.e., what would have been lost without protected area establishment). Third, consider zoning of activities to ensure the maintenance of effective management. Finally, remind citizens to think about conservation when they vote, including holding politicians accountable for their environmental promises. Without tackling resistance to expanding the protected estate, it will be impossible to reach conservation targets, and this will undermine attempts to stem the global extinction crisis.
\end{abstract}




\section{Introduction}

Protected areas have been the core of conservation efforts for many decades (Watson et al. 2014), and they have been critical in protecting many species, communities, and ecosystems (Rodrigues et al. 2004; Laurance et al. 2012). Under key initiatives such as the Aichi targets (among others), there is a concerted push to expand the protected area to $17 \%$ of the world's terrestrial surface area, although some scientists argue much higher levels of protection - up to $50 \%$ or more - are both needed and feasible for biodiversity protection (Noss \& Cooperrider 1994; Wilson 2016; Dinerstein et al. 2017). Yet simultaneous with these ambitious global targets, and at a time of unprecedented biodiversity loss (and hence when protected areas are increasingly needed), there is strong resistance to protected-area expansion. Sometimes the resistance is from local people or industries, but in other cases the general public supports increased protection of lands and waters, whereas elected officials do not. This problem is apparent in both terrestrial and marine environments and in developed and developing countries.

We examined 3 cases of strong push-back against the establishment of protected areas from Australia, North America, and Germany. We then considered some of the possible contributing factors to this problem and outline potential solutions. We argue there is an urgent need to build a broader and more diverse constituency for the establishment of protected areas and their subsequent management, especially in light of findings that protected areas associated with positive socioeconomic outcomes tend to achieve better conservation outcomes (Oldekop et al. 2016). Stronger advocacy for protected areas must extend beyond biodiversity-based arguments for nature conservation to encompass wellarticulated business cases incorporating the economic, human health, and other benefits of protected areas yet still appeal to the strong emotional attachment people inherently have to nature. 


\section{Brief case studies}

Government and community support for reserve expansion is failing in some parts of the world, including in developed, affluent nations like Australia (e.g., see http://www.abc.net.au/news/2014-03-05/abbott-timber-industry-dinner-forestry-councilforest-locked-up/5299046), North America, and Germany, where it might be expected that such initiatives would be welcomed.

\section{Victoria, Australia}

In southeastern Australia, there have been widely communicated arguments for the establishment of a large protected area in the iconic Mountain Ash (Eucalyptus regnans) forests, which are close to the city of Melbourne. The Mountain Ash ecosystem supports some of the tallest flowering plants on Earth but is at high risk of ecosystem collapse based on IUCN Red List ecosystem assessment criteria (Burns et al. 2015). An expanded reserve system is critical not only for the maintenance of the ecosystem (Burns et al. 2015) but also to prevent the extinction of critically endangered species like Leadbeater's possum (Gymnobelideus leadbeateri) (Todd et al. 2016; Taylor et al. 2017). There are also economic, employment, water-production, and carbon-storage arguments that favor expansion of protected areas (Keith et al. 2016; Keith et al. 2017). A series of local and statewide opinion polls has repeatedly shown strong public support for expanding the system of protected areas in the Mountain Ash forests. Despite continued efforts by conservationists, resistance from the timber industry and parts of government (Lindenmayer 2017) make a shift from woodproduction forest to a national park unlikely.

\section{Bavaria, Germany}

The oldest national park in Germany, the Bavarian Forest National Park, was established in $1970\left(242 \mathrm{~km}^{2}\right)$, and the adjacent Šumava National Park $\left(680 \mathrm{~km}^{2}\right)$ in the 
Czech Republic was established in 1991. Today, these national parks represent the largest contiguous forest landscape in Central Europe. Windthrow and outbreaks of bark beetles have created a species-rich forest landscape, following a "benign-neglect" strategy that prohibited salvage logging of affected areas in the core zones of the park (Müller et al. 2010). Not surprisingly, local resource-based communities, which have a long history of forest utilization, regarded the bark beetle a threat that should be controlled by salvage logging. Long-term interdependence between people and the forest has made the forest one of the central markers of the identity of local people (Job \& Mayer 2012). This complex socioecological context of extensive natural disturbances promoted political conflicts and significant push-back against the expansion of the Bavarian Forest National Park in 1997. This example demonstrates that local communities with strong ties to a specific landscape altered by the nonintervention strategy of park managers- can raise significant resistance to the expansion of protected areas (Müller 2011). Today, tourism in the Bavarian Forest National Park adds significantly greater value to the regional economy than the opportunity costs associated with the national park (Job \& Mayer 2012), similar to the tourism revenues in many other national parks in Germany (Mayer \& Woltering 2017). In fact, none of these parks has been established on the basis of broad public acceptance (i.e., a certain portion of local communities or special stakeholder groups has raised (or still raise) significant resistance to the establishment of protected areas (Mayer \& Stoll-Kleemann 2016). In July 2016, when the prime minister of Bavaria proposed an additional national park in the state, resistance by local communities was rekindled (see http://www.np3.bayern.de/).

\section{Florida, U.S.A.}

Florida represents an interesting case where one of the preeminent land conservation programs in the world was terminated, not due to lack of public support but because the state government consists of ideologues strongly opposed to conservation and aligned with 
development interests. A Land Acquisition Trust Fund was established by the Florida legislature in 1963. In 1990, in response to increased population growth and development pressure, funding for land acquisition was increased to \$US300 million per year for 10 years by the Preservation 2000 Act. This program was extended through 2010 by the Florida Forever Act of 1999 (Tear et al. 2005). Florida conservation lands, including multiple-use lands such as national and state forests, currently constitute $30.1 \%$ of the state (Florida Natural Areas Inventory 2017) (I've emailed Reed to see if he agrees with this citation change). Nevertheless, given that Florida is the hottest spot, in terms of endemism, within a newly recognized global biodiversity hotspot (Noss et al. 2015), and that wide-ranging species such as the Florida panther (Puma concolor) are negatively affected by habitat fragmentation, conservationists argue that more land needs to be protected. However, under a state legislature hostile to conservation, appropriations for land acquisition were slashed in 2009 and have not recovered since.

The people of Florida responded to the cessation of state support for land conservation by passing an amendment to the state's constitution, the Florida Water and Land Conservation Initiative in 2014 , which was approved by $75 \%$ of voters. The legislature and governor of Florida found a way to avoid following the intent of this amendment, and virtually no money has been allocated to land acquisition. The latest attempt to restore funding to the Florida Forever program failed, with the legislature allocating zero dollars in 2017 (Associated Press 2017). This example from Florida demonstrates that even with widespread public support for increased land conservation, political leaders beholden to special interests such as real-estate developers have the ability to ignore the public will. 


\section{Key lessons}

Our case studies indicate that governments, industries, and local communities may resist the expansion of protected areas, and at least four key reasons underpin such resistance: a failure of the conservation community to strongly articulate the diverse values of protected areas; the conservationist argument for expanded protected areas not encompassing broader ecosystem service, recreation, and aesthetic values; the potential for exclusion of some activities that will disenfranchise some key stakeholder groups, and; the potential for protected-area establishment to interfere with land development, which leads to political resistance to conservation even where the majority of the public supports it. We considered these problems and suggest ways to resolve them.

Broaden the case for reserves beyond protecting species, communities, and ecosystems

The case for expanding protected areas is often underpinned by arguments for protecting species, communities, and ecosystems (biodiversity). But these arguments may not resonate strongly with politicians and other decision makers (if they resonate at all) or with rural people who might be affected most directly by increased land protection. The benefits of protected areas are widespread, but they are diffuse, whereas the costs of conservation are concentrated on particular stakeholders who often hold substantial political power (see below). We suggest promotion of additional values of protected areas is needed to strengthen the case for protected areas and make public support for them deep as well as wide. These include the economic, human-health, education, carbon-storage, and water-production values, the maintenance of which will often be compatible with biodiversity values. The history of conservation supports such a diverse strategy. In North America, one of the most successful and revered conservationists is Aldo Leopold, who applied a broad range of economic, recreational, scientific, and ethical arguments for conservation, depending in part on whether 
he was addressing farmers, hunters, politicians, wilderness advocates, or fellow scientists (Meine 1988).

Cases against national parks and other protected areas are often framed around economic losses and eroded employment opportunities associated with a loss in commodity production (e.g., timber). To counter this, advocates for protected areas need to build an economic- and employment-based business case for land-tenure change (e.g., Nous Group 2017). Indeed, numerous well documented cases exist in which a transition away from extractive industries to protected areas has led to a considerable improvement in economic and employment outcomes, including more, better paid, and longer-lasting jobs (Powers 1998; Buckley 2014; Mayer \& Woltering 2017). As an example, Keith et al. (2017) used the United Nations System of Economic and Environmental Accounting framework (United Nations 2012) to demonstrate a 21-times difference in the contribution to the regional GDP from nature-based tourism relative to native forest wood production. Such formalized accounting procedures emphasize the direct economic benefits of protected areas and show they can significantly outweigh the costs of a land-tenure change. A business model can subvert the normal reactive process in conservation, where a major land-development proposal is made (e.g., a new mine, road, timber sale, urban settlement) that triggers opposition from environmental groups. Rather, the business case for a given protected area may demand that advocates for alternative land uses have the burden of proving the benefits of their industries outweigh those of the protected area.

Part of the business case for expanded protected areas may include the establishment of walkways, trails, and other infrastructure to provide increased human access and recreation. Such infrastructure will often be critical to realize tourism and associated economic potential (Buckley 2014) as well as human health benefits and, in turn, to build a constituency of community support for a protected area. Opportunities created by such 
infrastructure may help dilute opposition to expanded protected areas, especially if employment opportunities are local or regional in contrast to resource-extraction jobs, which often can be distant from where resources are harvested or removed. Of course, the impact of accommodating increased visitor access needs to be carefully managed to avoid degrading the array of key values for which a protected area was established in the first place. Ecologically sensitive areas must be protected from overuse.

Beyond direct economic and employment opportunities, there is also a need to account for other benefits of protected areas such as for human health (including mental health) (Chivian \& Bernstein 2008), education, carbon storage, and water production. The importance of natural environments, including protected areas, for promoting human wellbeing is well documented (Louv 2005; Zaradic \& Pergams 2007), and the associated indirect economic benefits are substantial (Chivian \& Bernstein 2008). The annual contribution of state parks to the economy in terms of recreation services in the United States was estimated in 2012 to be $\$$ US14 billion (Siikamaki 2011). The state government of Victoria, Australia, completed a broad assessment of their reserve system; analyses revealed an estimated value of \$AU1.3 billion annually for a range of values associated with this natural asset (e.g., for water production and pollination services) (Parks Victoria 2015)). Similarly, for the area targeted for reserve expansion in the Mountain Ash forests of Victoria, environmental accounting indicated the economic value of water production for the city of Melbourne from a proposed park was 25.5 times the value of timber production from the same forests if they were not reserved (Keith et al. 2017).

Several additional key issues are associated with building a business case for protected areas, including articulating their potential ecosystem service and other contributions to the economy. One of these issues is the spatial scale and scale of human influence at which ecosystem service values are important. This has been examined, for 
example, through the economic and environmental accounting work in the Central Highlands of Victoria, where the water-supply ecosystem service is relevant to more than 4 million people living up to $120-150 \mathrm{~km}$ away from where water is harvested. This, in turn, underpins the much higher added value of water relative to timber from these forests (Keith et al. 2016). Such ecosystem service values for water shows it is competitively superior to the extractive benefits of timber production. The substantial carbon sequestration and storage value of the same forests is, of course, a global ecosystem service in terms of efforts to tackle climate change (Keith et al. 2009), but its economic value under a carbon-market pricing arrangement also exceeds the timber value at a regional scale (Keith et al. 2016).

A second key issue associated with building a business case for, and overcoming resistance to, expanded protected areas is dealing with those who hold political power and can sometimes have excessive economic- and labor-market influence (Lindenmayer 2017). Conservationists advocating for expanded protected areas need to engage with these economic drivers and beneficiaries and be aware of the political implications of the concentrated pain and diffuse benefits phenomenon. That is, the (often relatively small) group of people who benefit from resource exploitation (e.g. timber companies and land developers) will fight hard to maintain access to resources (and instruments like subsidies and tax breaks that facilitate access) because they stand to lose a lot (equating to concentrated pain) from land conversion to protected areas. Conversely, the expansion of a protected area will have diffuse benefits to a large number of people (including some who may never visit reserves). The concentrated pain and diffuse benefits phenomenon favors decision making that preserves the exploitative rights of the few. Solutions to this problem demand the development of creative ways to influence decision making (Lindenmayer 2017). Communicating the relative values of natural assets to the economy such as through environmental accounting provides one avenue for strengthening the case for protected areas 
and their associated ecosystem-service values relative to extractive benefits like those from timber production (see Keith et al. 2016). Another approach is to conduct scenario planning (sensu Peterson et al. 2003) in which the ecological, economic, and employment implications of expanding the protected area network can be projected against alternative management regimes such as those based on resource extraction.

Better explain and advocate for conserving native species and natural ecosystems in protected areas

There is substantial scientific literature on the conservation values of protected areas and an associated body of knowledge on reserve design (Worboys et al. 2015). However, the conservation benefits of protected areas, including for species at risk of extinction, is often not well communicated, especially to a broader audience beyond that of other scientists. We argue that conservation biologists and park managers must work harder to highlight how many species, communities, and ecosystems have been conserved by protected areas and also the counterfactual - what would have been lost without protected-area establishment. This may be especially important in places like Florida, where levels of reservation appear to be relatively high, but nevertheless the protected-area estate needs to be expanded to prevent significant losses of biodiversity (Dinerstein et al. 2017). We also suggest that currently too many conservation biologists incorrectly assume the public and decision makers share their appreciation for biodiversity. Greater communication efforts are needed to generate more interest in, and passion for, the conservation of biodiversity among nonscientists. However, we acknowledge that effective conservation communication is a major challenge because some western cultures are increasingly adopting both an antienvironment ideology and an antievidence agenda, where scientific knowledge and evidence are disregarded (RussellSmith et al. 2015; Lubchenko 2017). As outlined in the preceding section, the effectiveness 
of the conservation case for protected areas might be strengthened if biodiversity conservation is considered part of a broader portfolio of values.

Consider zoning of activities and ensure the maintenance of effective management

Some communities fear the establishment of protected areas will limit access to particular areas or preclude particular activities (e.g. hunting, fishing, firewood collection). Part of the solution to this problem is to ensure that advocates for expanded protected areas are more sympathetic to access issues and, for example, recommend zoning systems within protected areas or adjacent multiuse zones where some kinds of activities can continue to be practiced (Noss \& Harris 1986). This approach has been fundamental to the biosphere reserve strategy since its inception (UNESCO 1974) and has been recommended for adoption in many types of landscapes (e.g. Harris 1984; Noss \& Harris 1986; Geneletti \& van Duren 2008). Zoning, coupled with the development of infrastructure (see above) also may be important to concentrate and control increased visitor numbers in particular places and limit damage to other parts of protected areas.

Some opponents of expanded protected areas argue the effectiveness of management will be diminished as a result of a change in land tenure. Some protected areas are poorly managed or even completely lack management (Watson et al. 2014). Significant numbers of species can be lost from some protected areas in the absence of effective interventions to tackle key threatening processes (Woinarski et al. 2015). As an example, for ecosystem types dependent on frequent fire, even a few years without fire can result in reproductive failures of fire-dependent species and can ultimately lead to an alternative stable state (Noss 2017). A change in land tenure must not be associated with a disinvestment in management, although the kind of management will likely change. Indeed, greater levels of management may be needed with increased visitor numbers (e.g., steeply rising park attendance in the United 
States [National Park Service 2016]). Therefore, some of the increased economic benefits generated from protected areas must be reinvested to ensure these places are appropriately managed. For example, although the economic, social, and icon value of the Great Barrier Reef has recently been estimated to exceed \$AU50 billion dollars (Deloitte Access Economics 2017), it has long been known that management agencies are chronically underfunded to deal with rapidly increasing numbers of visitors (Driml \& Common 1995).

Remind people to think about conservation when they vote

In most modern democracies, the majority of people are positively inclined toward nature and support land conservation. Conservation can be a key issue in major elections. For example, stopping the damming of an iconic river in Tasmania was a determining issue in the 1983 Australian Federal election, which some political analysts consider contributed to a particular party being elected. Similarly, ceasing old-growth logging is believed to have been instrumental in a change of government in Western Australia in 2001. Yet, incongruously, voters often elect politicians hostile to establishment of protected areas. Apparently, voters are not thinking primarily about conservation when they head to the voting booths; they are thinking about jobs, taxes, or other ostensibly more immediate concerns. This problem suggests that support for conservation, although widespread, is unfortunately often shallow.

We suggest conservationists must work more closely with the mainstream media and social media to develop campaigns that remind people what nature means to them and how important it is to vote for people who share a concern for nature. Perhaps the theme that resonates most strongly is quality of life and human health (Chivian \& Bernstein 2008) because people prefer an attractive landscape that supports biodiversity and is characterized by open space and low traffic volume to a totally developed and polluted landscape with subdivisions, strip malls, and traffic jams. Less developed landscapes are also healthier for 
people both physically and emotionally (Louv 2005; Chivian \& Bernstein 2008). Land conservation helps protect and enhance quality of life for people, a fact that conservationists should communicate more strongly.

\section{Conclusions}

There is resistance to expanding the protected area network in the developed nations of Australia, Germany, and the United States, which have a strong past record of environmental management and nature conservation. Such resistance is evident within local communities as well as within governments and, if successful, will make it impossible to achieve key global reservation objectives like the Aichi targets and more ambitious and biologically defensible targets (Dinerstein et al. 2017). It also will undermine attempts to stem the looming extinction crisis (Maxwell et al. 2016). To counter resistance, conservation professionals must argue more strongly for both the values of existing protected areas and the critical need for new and expanded reserves. These arguments can be strengthened by diversifying the range of reasons protected areas are important, including economic, human health, and other benefits. Extensive communication of these additional values will be essential both to building a strong constituency of supporters for expanded protected area systems and to swaying often economically and policy-conservative decision makers.

A business-case approach for protected areas may often include the establishment of built infrastructure to facilitate greater access for human recreation, although this will need to be carefully managed (such as through zoning) to avoid degrading sensitive areas with high biodiversity values. Finally, a business case based on formal processes like economic and environmental accounting has significant potential for promoting the values of protected areas in a format and language likely to resonate with politicians and other policy makers.

\section{Acknowledgments}


We thank handling editor Paul Beier and 2 anonymous referees for insightful comments that greatly improved an earlier version of the manuscript. T. Boyer and C. Shepherd assisted with manuscript preparation.

\section{Literature Cited}

Associated Press. 2017. Highlights from Florida's new \$83 billion budget. U.S. News and World Report 9 May. Available from https://www.usnews.com/news/beststates/florida/articles/2017-05-09/highlights-from-floridas-new-83-billion-budget (accessed September 2017).

Buckley, R. 2014. Tourism. Pp. 175-182 in D. B. Lindenmayer, S. Dovers and S. Morton (Ed). Ten commitments revisted. Securing Australia's future environment. CSIRO Publishing, Melbourne.

Burns, E. L., Lindenmayer, D. B., Stein, J., Blanchard, W., McBurney, L., Blair, D., Banks, S. C. 2015. Ecosystem assessment of mountain ash forest in the Central Highlands of Victoria, south-eastern Australia. Austral Ecology 40:386-399.

Chivian, E., Bernstein, A. 2008. Sustaining life. How human health depends on biodiversity. Oxford University Press, Oxford, England.

Deloitte Access Economics. 2017. At What Price? The Economic, Social and Icon Value of the Great Barrier Reef. Deloitte Access Economics, Brisbane, Australia.

Dinerstein, E., et al. 2017. An ecoregion-based approach to protecting half the terrestrial realm. BioScience 67:535-545.

Driml, S., Common, M. 1995. Economic and financial benefits of tourism in major protected areas. Australian Journal of Environmental Management 2:19-29.

Florida Natural Areas Inventory (FNAI). 2017. Summary of Florida conservation lands. FNAI, Tallahassee. 
Geneletti, D., van Duren, I. 2008. Protected area zoning for conservation and use: A combination of spatial multicriteria and multiobjective evaluation. Landscape and Urban Planning 85:97-110.

Harris, L. D. 1984. The fragmented forest: Island biogeographic theory and the preservation of biotic diversity. University of Chicago Press, Chicago, Illinois.

Job, H., Mayer, M. 2012. Forestry vs. Nature protection in forests: regional economic opportunity-costs of the Bavarian Forest National Park. Allgemeine Forst Und Jagdzeitung 183:129-144.

Keith, H., Mackey, B. G., Lindenmayer, D. B. 2009. Re-evaluation of forest biomass carbon stocks and lessons from the world's most carbon-dense forests. Proceedings of the National Academy of Sciences 106:11635-11640.

Keith, H., Vardon, M., Stein, J., Stein, J., Lindenmayer, D. B. 2016. Experimental Ecosystem Accounts for the Central Highlands of Victoria v.1.0. The Australian National Univesrity, Canberra.

Keith, H., Vardon, M., Stein, J., Stein, J., Lindenmayer, D. B. 2017. Experimental Ecosystem Accounts for the Central Highlands of Victoria v.2.0. Version 2.0 May 2017. The Australian National University, Canberra, Australia.

Laurance, W. F., et al. 2012. Averting biodiversity collapse in tropical forest protected areas. Nature 489:290-294.

Lindenmayer, D. 2017. Halting natural resource depletion: Engaging with economic and political power. The Economic and Labour Relations Review 28:41-56.

Louv, R. 2005. Last child in the woods. Saving our children from nature-deficit disorder. Algonquin Books of Chapel Hill, Chapel Hill, North Carolina.

Lubchenko, J. 2017. Environmental science in a post-truth world. Frontiers in Ecology and Environment 15:3. 
Maxwell, S., Fuller, R. A., Brooks, T., Watson, J. 2016. Biodiversity: The ravages of guns, nets and bulldozers. Nature 536:143-145.

Mayer, M., Stoll-Kleemann, S. 2016. Naturtourismus und die Einstellung der lokalen Bevölkerung gegenüber Großschutzgebieten. Natur und Landschaft 91:20-25.

Mayer, M., Woltering, M. 2017. Nature tourism in Germany's protected areas. Pp. 12-22 in J.

S. Chen and N. K. Prebensen (Ed). Nature tourism. Taylor \& Francis eBooks, London.

Meine, C. 1988. Aldo Leopold: His life and work. University of Wisconsin Press, Madison.

Müller, J., Noss, R. F., Bussler, H., Brandl, R. 2010. Learning from a “benign neglect strategy" in a national park: Response of saproxylic beetles to dead wood accumulation. Biological Conservation 143:2559-2569.

Müller, M. 2011. How natural disturbance triggers political conflict: Bark beetles and the meaning of landscape in the Bavarian Forest. Global Environmental Change 21:935-946.

National Park Service. 2016. America's National Parks: Record Number of Visitors in 2015, Available from https://www.nps.gov/aboutus/news/release.htm?id=1775 (accessed July 2017). Noss, R. F., Harris, L. D. 1986. Nodes, networks, and MUMs: preserving diversity at all scales. Environmental Management 10:299-309.

Noss, R. F., Cooperrider, A. 1994. Saving nature's legacy: Protecting and restoring biodiversity. Island Press, Washington, D.C.

Noss, R. F., Platt, W. J., Sorrie, B. A., Weakley, A. S., Means, D. B., Costanza, J., Peet, R. K. 2015. How global biodiversity hotspots may go unrecognized: Lessons from the North American Coastal Plain. Diversity and Distributions 21:236-244.

Noss, R. F. 2017. Fire ecology of Florida and the southeastern coastal plain. University Press of Florida, Gainesville, Florida (in press).

Nous Group. 2017. Great Forest National Park: economic contribution of park establishment, park management, and visitor expenditure. Nous Group, city. 
Oldekop, J. A., Holmes, G., Harris, W. E., Evans, K. L. 2016. A global assessment of the social and conservation outcomes of protected areas. Conservation Biology 30:133-141.

Parks Victoria. 2015. Valuing Victoria's parks. Parks Victoria, Melbourne.

Peterson, G. D., Cumming, G. S., Carpenter, S. R. 2003. Scenario planning: a tool for conservation in an uncertain world. Conservation Biology 17:358-366.

Powers, T. M. 1998. Lost landscapes and failed economies. Island Press, Washington, D.C.

Rodrigues, A. S. L., et al. 2004. Effectiveness of the global protected area network in representing species diversity. Nature 428:640-643.

Russell-Smith, J., Lindenmayer, D. B., Kubiszewski, I., Green, P., Costanza, R., Campbell, A. 2015. Moving beyond evidence-free environmental policy. Frontiers in Ecology and Environment 13:441-448.

Siikamaki, J. 2011. Contributuions of the US State park system to nature recreation. Proceedings of the National Academy of Sciences of the USA 108:14031-14036.

stpetersblog. 2017. Budget deal includes no money for Florida Forever. Available from http://saintpetersblog.com/budget-deal-includes-no-money-florida-forever/ (accessed July 2017).

Taylor, C., Cadenhead, N., Lindenmayer, D. B., Wintle, B. A. 2017. Improving the design of a conservation reserve for a critically endangered species. PLOS One 12 (e0169629) doi:10.1371/journal.pone.0169629

Tear, T. H., et al. 2005. How much is enough? The recurrent problem of setting measurable objectives in conservation. BioScience 55:835-841.

Todd, C. R., Lindenmayer, D. B., Stamation, K., Acevedo-Catteneo, S., Smih, S., Lumsden, L. F. 2016. Assessing reserve effectiveness: Application to a threatened species in a dynamic fire prone forest landscape. Ecological Modelling 338:90-100.

UNESCO. 1974. Task Force on Criteria and Guidelines for the Choice and Establishment of Biosphere Reserves Man and the Biosphere Report No. 22. UNESCO, Paris. 
United Nations. 2012. System of Environmental-Economic Accounting Central Framework. United Nations, New York.

Watson, J. E., Dudley, N., Segan, D. B., Hockings, M. 2014. The performance and potential of protected areas. Nature 515:67-73.

Wilson, E. O. 2016. Half earth: Our planet's fight for life. W.W. Norton, New York.

Woinarski, J. C., Burbidge, A. A., Harrison, P. L. 2015. Ongoing unraveling of a continental fauna: Decline and extinction of Australian mammals since European settlement. Proceedings of the National Academy of Sciences of the USA 112:4531-4540.

Worboys, G. L., Lockwood, M., Kothari, A., Feary, S., Pulsford, I. (eds). 2015. Protected area governance and management. ANU Press, Canberra, Australia.

Zaradic, P. A., Pergams, O. R. 2007. Videophilia: implications for childhood development and conservation. The Journal of Developmental Processes 2:130-144. 